\title{
Collaboration of Pancasila and Civic Education Teachers and Guidance Counseling Teachers in the Developing of Student Characters in Senior High School
}

\author{
Monica Tiara $^{1}$, Neviyarni ${ }^{2}$, Mudjiran $^{3}$, Herman Nirwana $^{4}$ \\ Universitas Negeri Padang Jl. Prof. Dr. Hamka, Air Tawar. Padang-Sumatera Barat ${ }^{1,2,3,4)}$. \\ monicatiara@unp.ac.id
}

\begin{abstract}
This article aims to establish the collaboration between the Pancasila and Civic Education teacher and the Guidance Counseling teacher in developing the character of students in high school. This article is the result of a descriptive qualitative research study by selecting informants using the purposive sampling method. Data collection techniques used were observation, interviews, and documentation. Data were analyzed through data reduction steps and conclusion drawing. The technique for checking the validity of the data is the triangulation of sources. The results showed that the formation of students' character in the school could be carried out optimally if the teacher especially the Pancasila and Civic Education teacher collaborated with the Guidance Counseling teacher. Collaboration is carried out in the form of assignments for the preparation of student activity journals assigned by Pancasila and Civic Education teachers. The activity journal is prepared based on the Guidance Counseling teacher's input after the students conduct counseling related to the reported activity. Through these activity journals, the Pancasila and Civic Education teacher can identify obstacles in character formation and then look for solutions together with the Guidance Counseling teacher.
\end{abstract}

Keywords: Teacher Collaboration,Civic Education, Guidance Counseling, Character

\begin{abstract}
Abstrak. Artikel ini bertujuan untuk mengungkapkan kolaborasi yang dilakukan guru Pendidikan Pancasila dan Kewarganegaraan dan Guru Bimbingan Konseling dalam pembentukan karakter siswa di SMA. Artikel ini merupakan hasil kajian penelitian kualitatif deskriptif dengan pemilihan informan menggunakan metode pusposive sampling. Teknik pengumpulan data yang digunakan adalah observasi, wawancara dan dokumentasi. Data dianalisis melalui langkah-langkah reduksi data dan penarikan kesimpulan. Teknik pemeriksaan keabsahan data dilakukan dengan triangulasi sumber. Hasil penelitian menunjukkan bahwa pembentukan karakter siswa di Sekolah dapat terlaksana secara optimal jika guru khususnya guru Pendidikan Pancasila dan Kewarganegaraan melakukan kolaborasi dengan guru Bimbingan Konseling. Kolaborasi dilakukan dalam bentuk pemberian penugasan penyusunan jurnal aktivitas siswa yang ditugaskan oleh guru Pendidikan Pancasila dan Kewarganegaraan. Jurnal aktivitas tersebut disusun berdasarkan masukan guru Bimbingan Konseling setelah siswa melakukan konseling terkait aktivitas yang dilaporkannya. Melalui jurnal aktivitas tersebut guru Pendidikan Pancasila dan Kewarganegaraan dapat mengidentifikasi hambatan dalam pembetukan karakter dan kemudian mencari solusi Bersama dengan guru Bimbingan Konseling.
\end{abstract}

Kata Kunci: Kolaborasi Guru, Pendidikan Pancasila dan Kewarganegaraan, Bimbingan dan Konseling, Karakter 


\section{INTRODUCTION}

Law No. 20/2003 concerning the National Education System reveals that national education functions to develop capabilities and shape the character and civilization of a dignified nation to educate the life of the nation, and aims to develop the potential of students to become human beings who believe in and devote to God Almighty, noble, healthy, knowledgeable, capable, creative, independent, and become citizens of a democratic and responsible.

The law mandates that the purpose of education is not just to make students academically smart. But it must also be able to print the next generation who has a character and character. This means that character education becomes an urgent matter in our education system. Character education is the foundation of the national education system. Therefore, the main objective of this education must be a collective reflection, especially for educators or teachers, including parents.

So, education must be held by paying attention to the need for the formation of student character through learning (Monica: 2019). As the Pancasila and Civic Education subjects carry the mission of character education as expressed by Chlosin (2011) the Pancasila and Civic Education subjects are subjects which have a material content of political democracy, which is expanded with other sources of knowledge, positive influences of school education, society, parents, all of which are processed to train students to think critically, analytically, and act democratically in preparing for a democratic life based on Pancasila and The Republic of Indonesia Constitution of 1945.

This indicates that the character values taught through Pancasila and Civic Education learning include core character values and main character values. The main character values of Pancasila and Civic Education subjects include: religiousness, honesty, intelligence, toughness, democratization, and social care. While the main character values of Civics courses are nationalism, obedience to social rules, respect for diversity, awareness of the rights and obligations of self and others, responsible, logical thinking, critical, creative, and innovative and independence (Ministry of National Education, 2010: 19).

These character values are the responsibility of Pancasila and Civic Education teachers to be developed through learning and non-learning activities. To form optimal student character through Pancasila and Civic Education subjects, Pancasila and Civic Education teachers need to make special efforts one of them by collaborating with other teachers such as Guidance Counseling teachers. This is because, Guidance Counseling are also an important part in shaping the character of students in school. Guidance Counseling teacher or counselor manages the program including arranging programs, implementing and evaluating 
Guidance Counseling programs to help students develop optimally according to student needs.

Guidance Counseling is needed to support the formation of student character. In the Guidance for Guidance for School Guidance Program in Marsudi (2007) it is stated that school guidance is a process of assistance to students by paying attention to students as individuals and social beings, as well as paying attention to individual differences, so that students can make the optimal progress in their development process as well as can help himself, analyze and solve his problems, all for the sake of achieving happiness in life, especially the achievement of mental well-being.

Considering the need for cooperation from various parties in shaping the character of students, this article will further discuss how the collaboration of Pancasila and Civic Education teachers and Guidance Counseling Teachers in the formation of student character in high school.

\section{RESEARCH METHODS}

This article is a descriptive qualitative research study in which research procedures produce descriptive data in the form of written or oral words from people and observed behavior (Lexy: 2000). Meanwhile, descriptive research is a form of research aimed at describing or describing the phenomena that exist, both natural phenomena and human engineering. The purpose of descriptive research is to make a systematic, factual, and accurate assessment of the facts and the nature of a particular population or region. This research is used to find out how the collaboration of Pancasila and Civic Education teachers and Guidance Counseling teachers in forming the character of students at SMA Negeri 1 Padang.

Data collection techniques according to Arikunto are ways that can be used by researchers to collect data, where the method shows in an abstract, can not be realized in visible objects, but can be exhibited their use (Suharsimi: 2002). So this research data collection technique uses the method of observation, interviews and documentation.

The validity of the data in this study was determined using source triangulation. Source triangulation is used to check data about its validity, comparing the results of interviews with the contents of a document by utilizing various sources of information data for consideration (Sugiyono: 2008). In this case the authors compare the data from observations with data from interviews, and also compare the results of interviews with other interviews.

\section{DISCUSSION}

Formation of student character through learning and non-learning activities needs to be done. It aims to shape the child's personality, so that he becomes a good human 
being, a citizen, and a good citizen. As stated by Lickona (1991) that character education is a deliberate effort to help someone so that he can understand, pay attention, and do core ethical values. In other words Lickona shows in the formation of character there is a process of development that involves knowledge (moral knowing), feelings (moral feeling), and actions (moral action), while also providing a solid basis for building a coherent and comprehensive character education.

One way to shape the character of students in high school is through learning activities on Pancasila and Civic Education subjects. This is suspected because in participating in Pancasila and Civic Education students must achieve three Civic competencies consisting of; Civic Knowledge (Civic knowledge), Civic Skills (Civic skills), and Civic Disposition (Civic character) (Branson: 1999). Of the three competencies that must be achieved, one of them is Civic Disposition (Civic character) which means that Civic character is a substantive and essential dimension of Pancasila and Civic Education subjects and the development of the two previous dimensions. Referring to this, the character development of students is done by instilling values consisting of; religiousness, honesty, intelligence, toughness, democratic, and caring. while the main character values of Civics subjects are nationalism, obedience to social rules, respect for diversity, awareness of the rights and obligations of self and others, responsibility, logical thinking, critical, creative, and innovative, and independence. These main character values can be developed more broadly, to strengthen the function of civil servants as character education.

Based on the findings of the research it was revealed that the formation of student character at SMA Negeri 1 Padang was carried out in the learning process that was guided by the teacher with various methods. However, in practice the teacher has difficulty especially in connecting teaching material with real life. So students see Pancasila Education and Civic as rigid learning and are limited to theory. As revealed by Muhajir (2019) that in fact the Pancasila and Civic Education material is actually a lot that can be taught according to the reality of student life. But, in practice, teachers find it difficult to develop material because of the variety as so it is not absorbed by students as a whole.

Considering the limitations of Pancasila and Civic Education teachers in shaping the character of students through learning activities, the Pancasila and Civic Education teacher collaborated with the Guidance Counseling teacher so that the formation of the character of SMA Negeri 1 Padang students continued in non-learning activities by Guidance Counseling teachers. Collaboration by the teacher in the form of cooperation, interaction, compromise of several elements related to both individuals, institutions and or parties involved directly and indirectly who 
receive the consequences and benefits. The values that underlie a collaboration are the same goals, common perceptions, willingness to process, mutual benefits, and honesty (Abdulsyani, 1994).

Collaboration between Pancasila and Civic Education teachers and Guidance Counseling teachers is done in the form of assigning journal compilation of student activities assigned by the Pancasila and Civic Education teachers. The journal is made in the form of a table made by students in a notebook, following the form of the table:

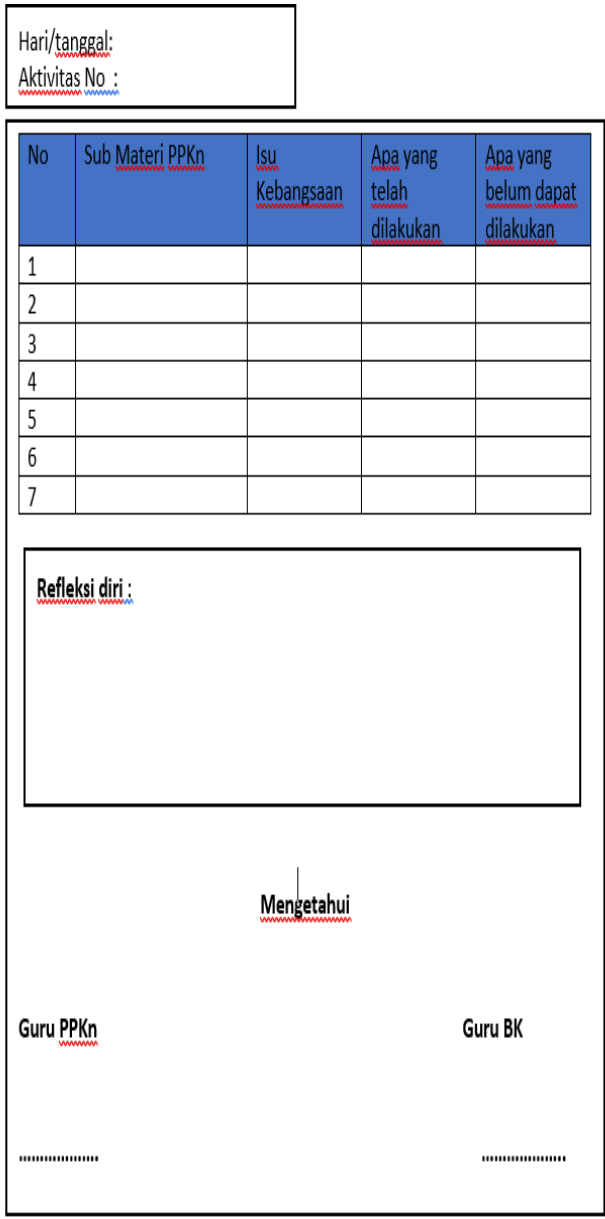

Figure.1 Journal of activities
The picture above is a journal of activities assigned by Pancasila and Civic Education teachers to students. The journal is a weekly assignment that must be fulfilled by students by the basic competencies at the meeting learned. The Pancasila and Civic Education teacher assigns students by giving instructions at the end of each lesson filling in and selecting submissions, national issues, what has been done and what hasn't been done. Filling in the column is assigned by the teacher with the consideration that Civic Education refers to several basic principles of active student learning, cooperative learning groups, participatory learning, and reactive teaching (Budimansyah: 2002). This is done by the teacher to train students' sensitivity to themselves and their environment, especially about the national environment. To fill the table to form students' characters optimally, the teacher assigns students to meet the Guidance Counseling teacher to achieve things that are not achieved in learning activities. Then every week students will do counseling with the Guidance Counseling teacher both individually and in groups to discuss the journal activities that have been made. The results of the counseling are written by 
students in the self-reflection box accompanied by the Guidance Counseling teacher.

Teacher collaboration of Pancasila Education and Civic with teachers Guidance Counseling is done with the consideration that one effective way in shaping the character of students can be done by way of counseling. As expressed by Eny (2017) Guidance Counseling teacher or familiar with school counselors has a role in shaping the character of students both inside and outside school learning. This shows that Guidance Counseling takes a large role in assisting each stage of learning / academic development, knowing themselves and their future opportunities, determining their goals and goals in life, and devising appropriate plans for achieving those goals, and overcoming personal problems (learning difficulties, relationship problems with friends, or problems with family). In other words Guidance Counseling Teachers can reach those not covered by Pancasila and Civic Education Learning, namely students to open themselves without being aware of their personal.

Through activity journals it is known that students' character development must follow their developmental stages. As

Kohlberg explained that all people go through these stages of moral development in the same order, because the higher stages require more complex reasoning than the previous stages. According to him, the higher the level of one's cognitive reasoning according to the stages of Piaget's development, the higher the level of one's moral reasoning (Sarwono, 2012).

According to Rest (1994), the best way to explain Kohlberg's stage of moral development is to see it as a six concept of how to hold social cooperation. This is what the Pancasila and Civic Education teacher and Guidance Counseling teacher did in shaping the character of students at SMA 1 Padang through collaboration as outlined in the activity journal. Journal of activities that have been completed at the end of the semester arranged by students in groups in the form of proposals and presented in front of other students and teachers of Pancasila Education and Civic and Guidance Counseling.

This collaboration also shows that the Guidance Counseling teacher can be a partner of subject teachers especially Pancasila and Civic Education subject teachers in shaping student character. Thus teachers who collaborate will be better 
prepared and able to synergize with other teachers. This is because the activity journal assigned by the teacher becomes a way to form students' character in habituation. Ganong W revealed that habituation was a reduction in the response from the previous response that was displayed when there was no reward or punishment after the stimulus was given. For example, if someone is given spicy food, at first the person cannot resist the spicy taste (Firmansah: 2017).

The assignment of activity journals conducted at each meeting can be a habituation that can influence one's behavior in their daily activities. So that the ability of self-reflection carried out by students continuously through activity journals does not directly foster the character values found in the contents of the journal for students.

\section{CONCLUSION}

Pancasila and Civic Education is learning that carries out the national mission of educating the nation's life through the corridor of "value-based education". for that the teacher has a key position in the formation of student character, but the limitations of subject teachers, especially the subjects of Pancasila and Civic Education requires teachers to innovate. One form of shaping the character of students in high school by Pancasila and Civic Education teachers can be done by collaborating with the Guidance Counseling teacher. This collaboration was carried out in the form of an activity journal assignment by the Pancasila and Civic Education teacher in which students were accompanied by the teacher in their preparation. Journal of activities is expected to bring up students' sensitivity to themselves and their environment because through the activity journal students can see the weaknesses and strengths so that the Pancasila and Civic Education teachers in learning activities can instill character values according to student needs and in nonlearning activities in the Guidance Counseling Teachers. Through counseling by strengthening students' self-concepts.

\section{REFERENCES}

[1] Monica Tiara, Neviyarni. 2019. Pendidikan Karakter Berwawasan Sosiokultural Di Sma Kota Padang. Jurnal Review Pendidikan dan Pengajaran. Volume 2 Nomor 2, Desember 2019. P-2655-710X e-ISSN 2655-6022 http://journal.universitaspahlawan.ac.id/inde x.php/jrpp.

[2] Cholisin. 2011. Pengembangan Karakter Dalam Materi Pembelajaran Pkn. Yogyakarta: Universitas Negeri Yogyakarta.

[3] Marsudi Saring, dkk. 2007. Layanan Bimbingan Konseling Di Sekolah. Surakarta: Muhhamadiyah University Press. 
[4] Lexy. J. Moleong, Metodologi Penelitian Kualitatif, (Bandung: PT Remaja Rosdakarya, 2000), hlm. 3

[5] Suharsimi Arikunto, Prosedur Penelitian Suatu Pendekatan Praktek, Jakarta : PT. Rineka Cipta, 2002, Cet.XII), hlm. 107.

[6] Sugiyono, Metode Penelitian Pendidikan Pendekatan Kuantitatif, Kualitatif, dan R\&D, (Bandung: Alfabeta, 2008), Cet. 6, hlm.272.

[7] Muhaimin, Rekonstruksi Pendidikan Islam, dari paradigma pengembangan menejemen kelembagaan kurikulum hingga strategi pembelajran, (Jakarta: PT. Raja Grafindo Persada, 2009), hlm325-327

[8] Muhajir, Nandri Sugiarti. 2019. Analisis Pelaksanaan Pembelajaran Pendidikan Pancasila dan Kewarganegaraan dalam Pembentukan Karakter Siswa SMP Muhammadiyah 1 Makassar. Jurnal Etika Demokrasi Pendidikan Pancasila dan Kewarganegaraan. Vol 4 Januari No. 12019

[9] Branson, M.S. (1999). Belajar Civic Education dari Amerika. Yogyakarta: LkiS.

[10] Eny Kusumawati. 2017. Peran Konselor Dalam Pembentukan Karakter Siswa. Prosiding Seminar Nasional. Universitas Ahmad Dahlan.

[11] Sarwono, S.W. (2012). Psikologi Remaja. Jakarta: PT Raya Grafindo Persada.

[12] Suardi, S., Herdiansyah, H., Ramlan, H., \& Mutiara, I. A. (2019). Implementasi Pendidikan Karakter Melalui Mata Pelajaran Pendidikan Kewarganegaraan di SMA Jaya Negara Makassar. JED (Journal of Etika Demokrasi), 4(1).

[13] Suardi, S., Megawati, M., \& Kanji, H. (2018). Pendidikan Karakter di Sekolah (Studi Penyimpangan Siswa di Mts Muhammadiyah Tallo). JED (Journal of Etika Demokrasi), 3(1).

[14] Rest, J. R. (1979). Revised Manual for the Defining Issues Test: An Objective Test of Moral Judgement Development.Minnesota: Minnesota Moral Research.
[15] Firmansah Kobandaha. 2017. Pendidikan Karakter melalui Pendekatan Habituasi. Jurnal IRFANI. ISSN 1907-0969 E ISSN 2442 - 8272 Volume 13.

http://journal.iaingorontalo.ac.id/index.php/ir 